\title{
The Impact of Emotions on the Intention of Sustainable Consumption Choices: Evidence from a Big City in an Emerging Country
}

\author{
Jianming Wang ${ }^{\mathrm{a} *}$, Longchang $\mathrm{Wu}^{\mathrm{a}}$ \\ a School of Business Administration, Zhejiang University of Finance \& Economics, 18 Xueyuan Road, Hangzhou, \\ Zhejiang 310018, China \\ * Corresponding author. Fax: +86 57187557430. \\ E-mail addresses: sjwjm@zufe.edu.cn (J. Wang),w7197u@163.com (L.Wu)
}

\begin{abstract}
Although increasing numbers of studies have linked emotions to sustainable consumption, little is known regarding the different effects that various emotions may have on specific sustainable consumption behavior. Based on research data that included 775 residents of Hangzhou, a big city in an emerging country, this paper studied the impacts of four emotions, i.e., pride, guilt, respect, and anger, on consumers' intention of sustainable consumption choice of household appliances. Using the partial least squares structural equation model, the results show that sustainable consumption choices of household appliances has two facets: resisting non-energy conserving household appliances and purchasing energy conserving household appliances. Pride, guilt, and respect all have positive impacts on both facets, whereas anger only has a positive impact on the latter. Pride is the most powerful influence among these four emotions. Furthermore, the resistance behavior can mediate the effects of pride, guilt, and respect on the purchase behavior. This study confirms that the four emotions can take active roles in promoting sustainable consumption and extends current knowledge in this area by 1) showing that respect
\end{abstract}


and anger can affect sustainable consumption choices significantly; 2) demonstrating that the impact of a specific positive emotion on the intention of sustainable consumption choices may not be stronger than a specific negative emotion; and 3) identifying the inner structure of sustainable consumption choices. Furthermore, this paper presents important implications for policy makers that pride appeal is a good option to promote energy conserving products.

Keywords: Sustainable consumption, Pride, Guilt, Respect, Anger, PLS-SEM

\section{Introduction}

Due to the number of environmental problems that threaten the environment and human life that have been identified over the last decades (Tanner \& Kast, 2003), sustainable development is one of the most pressing issues facing humanity. Unsustainable levels and types of consumption are at the heart of the sustainable development challenge (Princen, Maniates, \& Conca, 2002). Furthermore, without changes in our consumption behaviors, the contribution of advanced technologies, social initiatives, economic policies and production systems will be undermined in the pursuit of sustainable development, though these may all be indispensable influence factors (Peattie, 2010). Therefore, sustainable consumption behavior is a major concern for modern day societies and businesses (Costa Pinto, Herter, Rossi, \& Borges, 2014).

Heretofore, scholars have studied the promotion of sustainable consumption behavior for more than 40 years (Prothero et al., 2011). Some research has found that emotions play important roles when people are engaged in sustainable consumption 
behaviors (Carrus, Passafaro, \& Bonnes, 2008; Swim et al., 2011), with the exception of recognition, which is a common focus for scholars (Testa, Cosic, \& Iraldo, 2016). Further, Meneses (2010) and Kanchanapibul, Lacka, Wang, \& Chan (2014) found that sustainable consumption is correlated more with emotion than with cognition. Consistent with this opinion, a large number of scholars have studied how people can adopt sustainable consumption behavior following an emotional decision (Harth, Leach, \& Kessler, 2013; Peloza, White, \& Shang, 2013; Antonetti \& Maklan, 2014a). Furthermore, recent research has found that certain emotions have specific effects on particular types of sustainable behavior. For example, pride predicts intentions of in-groups to favor environmental protection, whereas anger predicts intentions to punish wrongdoers who have damaged the environment (Harth et al., 2013). In other words, an emotion may be capable of predicting specific types of sustainable consumption behaviors.

What is surprising is that very little research on sustainable consumption has explored the difference in the effects of various emotions on a specific sustainable consumption behavior. Our study contributes to this new area of research by proposing and testing conceptual models of the influence of pride, respect, guilt, and anger on consumers' intentions to choose environment-friendly products. This approach enables us to explore which emotion is most likely to predict a consumer's intention of sustainable consumption choices of household appliances (ISCCHA). Moreover, we provide a new perspective that places ISCCHA into two separate categories: intention to resist non-energy conserving household appliances (IRNCHA) 
and intention to purchase energy conserving household appliances (IPECHA).

To summarize, we aim to explore the inner structure of ISCCHA and to clarify the relationships between emotions (pride, guilt, respect, and anger) and ISCCHA such that more effective policies can be created.

\section{Literature review and hypotheses development}

Plenty of research has explored the relationship between emotion and sustainable consumption behavior, and the results clearly show that the former has a remarkable impact on the latter. These emotions include, but are not limited to guilt (Kaiser, 2006), pride (Onwezen, Bartels, \& Antonides, 2014), regret (Kim, Njite, \& Hancer, 2013), fear (Van Zomeren, Spears, \& Leach, 2010), anger (Van Zomeren et al., 2010), distress (Lee \& Holden, 1999) and sadness (Nerb \& Spada, 2001). It is worth mentioning that appealing to fear is a cliché in environmental campaigns (Maddux \& Rogers, 1983), an approach that is criticized by Oskamp (2000) because of the possibility that it will backfire and lead people to deny environmental threats, as well as Meneses (2010) for its many inevitable disadvantages (e.g., fear involves a threat to personal freedom). Moreover, among these emotions, certain emotions are placed into a special category, defined as self-conscious emotions. These emotions require self-awareness (Leary, 2004). People tend to experience them only when they become aware that they have lived up to, or failed to live up to an actual or ideal self-representation (Tracy \& Robins, 2004). Self-conscious emotions include guilt, shyness, pride, regret, shame, embarrassment, and so on (Bodolica \& Spraggon, 2011). More complex than basic emotions, self-conscious emotions are elicited by violations 
of personal or social norms (Tracy \& Robins, 2004), which are formed on the basis of ethical standards (Ketelaar \& Tung Au, 2003). Therefore, self-conscious emotions are ideal predictors of moral behaviors, such as sustainable consumption behavior. The four moral emotions studied in this paper are displayed in Table 1.

-Insert Table 1 about here-

\subsection{Specific emotion and sustainable consumption}

Pride is a positive emotion that is associated with a sense of achievement and self-worth (Antonetti \& Maklan, 2014a). Scholars distinguish two separate categories of pride: authentic pride and hubristic pride (Tracy \& Robins, 2007; McFerran, Aquino, \& Tracy, 2014). In sustainable consumption behavior research, researchers focus on the emotional reaction of authentic pride, which supports behaviors in accordance with personal standards or in pursuit of valued goals (Williams \& DeSteno, 2008). In light of this view, many scholars have researched the correlation between pride and sustainable consumption. For example, Antonetti \& Maklan (2014b) found that pride has positive influence on the consumer's future intentions to purchase sustainable products. Additionally, Onwezen et al. (2014) proved that pride regarding the environment mediates the effects of attitudes and social norms on the intention of sustainable consumption choices. Moreover, based on the results of empirical research, Onwezen, Antonides, \& Bartels (2013) proposed that pride modulates sustainable buying and travelling behaviors so that the choices align with one's personal norms. In short, pride has a significant and positive effect on an 
individual's sustainable consumption choices.

Guilt is a negative emotion that results when an individual feels responsible for a negative outcome (Baumeister, Stillwell, \& Heatherton, 1995). Chen (2015) found that if people feel responsible for the negative impact of global warming and climate change, this will significantly promote their energy saving and carbon reduction behavioral intentions. Therefore, guilt can stimulate individuals to break personal norms (Schwartz, 1977), whereas pride motivates compliance with personal norms. These feelings of guilt and pride have a distinct role in the individual's decision-making process for sustainable consumption behavior (Onwezen et al., 2013; Han, 2014). Hence recent research has studied pride and guilt independently, remaining consistent with sociopsychological theories that contain positive and negative facets of emotions (Perugini \& Bagozzi, 2001; Han \& Ryu, 2012). However, compared to pride, guilt is a more popular self-conscious emotion in sustainable consumption behavior studies. A number of pundits have studied either pride (Han, 2014) or guilt (Bamberg \& Möser, 2007; Peloza et al., 2013) with regard to sustainable consumption behavior. So far, all of those studies have indicated that guilt has a remarkable impact on the intentions of target behavior.

Respect is a self-conscious emotion that is based on the perspectives of the appraisal theory of emotion (Frijda, 1986) and cultural perspectives on emotion (Mesquita \& Frijda, 1992; Mesquita, 2003). It is a positive feeling that, when extended to another person, can be classified into two types: ought-respect and affect-respect. Ought-respect refers to the type of respect that everyone deserves 
based on political, moral, and legal considerations, whereas affect-respect is mostly an emotion that is generated in a specific social context or relationship (Li, 2006). The latter type of respect, which is the emotion we studied in this paper, occurs when an individual genuinely recognizes, acknowledges, and admires another for his or her merit, achievement, or moral qualities (Li \& Fischer, 2007). Scholars find that moral self-perfection is the most important learning goal among Chinese people ( $\mathrm{Li}, 2001$, 2003; Li \& Fischer, 2004), meaning they feel a strong respect for people who are exemplary in achieving these elements of their ideal life model, and they learn from and emulate these models to perfect themselves (Li \& Fischer, 2007). In summary, if someone respects the people who have performed sustainable consumption behavior, he or she is most likely to perform this type of behavior. Respect, as a general rule, may have a positive and significant impact on sustainable consumption behavior. However, respect is rarely studied in existing sustainable consumption research. Although Ianos, Peptenatu, \& Zamfir (2009) studied respect for the environment in the sustainable development of human society, this is not the type of respect to which we are referring in this paper.

Contrary to the three emotions mentioned above, anger is a non-self-conscious emotion (Carver, Sinclair, \& Johnson, 2010). Instead, it is termed a basic emotion (Tracy, Robins, \& Tangney, 2007). Anger is a negatively valenced and other-focused emotion that is not typically considered in the morally relevant sphere (Tangney, Stuewig, \& Mashek, 2007; Baumeister, Vohs, DeWall, \& Zhang, 2007). However, it is worth noting that righteous anger is significantly correlated with sustainable 
consumption behaviors. Righteous anger arises in response to a special class of anger-eliciting events, meaning those in which the perpetrator's behavior represents a violation of moral standards (Tangney et al., 2007). It can serve moral functions by motivating angry people to take action to remedy observed injustices (Rozin, Lowery, Imada, \& Haidt, 1999). Several scholars have studied the influence of anger on sustainable consumption behaviors. Nerb \& Spada (2001) found that anger elicited from reading a newspaper report about an environmental problem can affect a person's intention to boycott the transgressor who has polluted the environment. Similarly, Corral-Verdugo et al. (2009) studied the relationship between the respondents' indignation as they watched someone participate in damaging the environment and general ecological behavior (e.g., sustainable consumption, energy saving, or recycling). The results, which are consistent with Kals (1996) and Kals, Schumacher, \& Montada (1999), showed that indignation has a positive impact on those mentioned behaviors.

Based on the above, the first hypothesis is put forward as follows:

H1: Pride, respect, guilt, and anger all have positive influences on ISCCHA.

Based on the perspective of Frijda (2007), who argued that people are accustomed to pursuing positive emotions and avoiding negative emotions, some scholars have studied the impacts of positive emotions and negative emotions on sustainable consumption behavior simultaneously (Carrus et al., 2008; Chen, 2013; Koenig-Lewis, Palmer, Dermody, \& Urbye, 2014). However, Meneses (2010) extended the idea by studying the split between those two impacts, with results 
indicating that sustainable consumption behavior is correlated more with positive emotions than with negative emotions, a theory also confirmed by Chen (2013). Moreover, Harth et al. (2013) found that pride is the only one of the three emotions that predicts further achievement in environmental protection in a more positive, forward-looking, motivational way.

In view of these facts, the second hypothesis is put forward as follows:

H2: ISCCHA is more correlated with pride than with respect, guilt, or anger.

\subsection{Two facets of sustainable consumption choices of household appliances}

Roberts (1996) defined ecologically conscious consumer behavior as purchasing pro-environmental products and rejecting ecologically irresponsible products. Additionally, Black \& Cherrier (2010) found that anti-consumption (i.e., rejecting, reducing, and reusing) is more of an integral part of sustainable lifestyles than the purchase of green alternatives. This finding indicates that people have two sustainable choices when they are making purchase decisions. Specifically, consumers can choose not only to purchase green products but also to reject the purchase of anything that may harm the environment or be incompatible with their ideology on conservation (Sand1kc1 \& Ekici, 2009). Inspired by this opinion, we assume that people can have two types of sustainable consumption choices when they are shopping for a household appliance. That is, sustainable consumption choices of household appliances (SCCHA) can be classified into two types of intentional consumption choices concerning the environment: resisting non-energy conserving household appliances (RNCHA) and 
purchasing energy conserving household appliances (PECHA). The classification of consumption choices mentioned above is outlined in Table 2.

-Insert Table 2 about here-

RNCHA is a form of resistance to specific types of products. Most scholars study sustainability by focusing on the consumers' preferences for sustainable products, while overlooking the ways in which resistance also plays a key role in sustainability. For instance, Cherrier, Black, \& Lee (2011) found that consumer resistance to sustainable development is not a redundant concept, and this act actually helps to develop an informant's identity. With regard to the consumption of household appliances, RNCHA results in consumers not using high-energy-consuming appliances, potentially avoiding the creation of negative externalities, meaning social costs are greater than private costs. PECHA is a type of environmentally friendly buying behavior that not only can help consumers save energy, mitigating the negative influence on the environment but also promotes the development of green industries. Therefore, it mainly creates positive externalities, which means social benefits are greater than private benefits. Despite the different externalities that PECHA and RNCHA create, compared to PECHA, which costs money, RNCHA is an easier decision to make. Furthermore, PECHA inevitably will result in incidental non-consumption of non-energy conserving household appliances (Chatzidakis \& Lee, 2013), whereas RNCHA, which is an intentional behavior, can lead to one of three results: PECHA, buying substitutes for household appliance, or non-consumption of any product. In other words, resisting non-energy conserving household appliances 
and purchasing energy conserving household appliances are not the same thing, and this phenomenon should also appear in the consumer's corresponding intentions.

Therefore, the third hypothesis is put forward as follows:

H3: ISCCHA can be divided effectively into IRNCHA and IPECHA.

In line with the above hypotheses, and under the premise that consumers will purchase a household appliance to fulfill their functional demands (e.g., a refrigerator can keep food fresh and turn water into ice), two types of purchase procedures in sustainable consumption behaviors emerge: (1) Procedure 1: consumers choose energy conserving household appliances to meet their functional demands, and thus the entire purchase procedure is finished; (2) Procedure 2: consumers choose to reject non-energy conserving household appliances in the beginning, then keep seeking alternatives to meet their functional demands. In procedure 2, it is worth emphasizing that the sustainable consciousness of consumers was aroused after the non-energy conserving household appliance wasn't chosen for sustainable purposes, meaning they will be very likely to follow the sustainable consumption standards during the entire purchase procedure until they perform the purchase behavior. In other words, IRNCHA may have a positive influence on IPECHA.

Therefore, the fourth hypothesis is put forward as follows:

H4: In procedure 2, IRNCHA mediates the impact of pride, respect, guilt, and anger on IPECHA.

\subsection{Hypotheses and research models}


Our theoretical framework involves a total of four hypotheses and two models. Model 1 is a representation of procedure 1, whereas model 2 is a representation of procedure 2. $\mathrm{H} 1$ and $\mathrm{H} 2$ will be tested by models 1 and 2, and $\mathrm{H} 3$ and $\mathrm{H} 4$ will be tested by model 2 . The conceptual models are displayed in Fig. 1.

-Insert Fig. 1 about here-

\section{Methods}

This section describes the questionnaire, survey process and analysis tool. Information about the respondents' gender, age, education, and income were collected in the survey process.

\subsection{Measures}

All selected measures (details of the scales are available in Table 4) were answered using seven-point scales with labeled endpoints and are described in detail in the following sections. All items were translated into Chinese and checked by five English language professors prior to the formal investigation.

\subsubsection{Pride and guilt}

Pride and guilt were each measured with three items adapted from Onwezen et al. (2013) . These adopted instruments were modified to be adequate in the present study. To measure pride, the respondents were asked to rate the following items on a scale of one to seven, indicating the intensity of their emotion: "When I purchase energy conserving household appliances, I would feel satisfied/worthwhile/proud." To measure guilt, the respondents were asked to rate the following items on the same scale of one to seven: "When I purchase non-energy conserving household appliances, I would feel guilt/remorseful/bad."

\subsubsection{Anger}

Based on previous research on anger (Harth et al., 2013), three items measured 
this emotion: "When people purchase non-energy conserving household appliances, I would feel resent/disdain/angry." Respondents chose a score from one to seven to indicate the intensity of their anger.

\subsubsection{Respect}

Respect was measured using three items, developed on the basis of Chinese culture, previous psychological research (Li \& Fischer, 2007) and the approach used by Harth et al. (2013) to measure emotions: "When people purchase energy conserving household appliances, I would admire/appreciate/respect them." Respondents chose a score from one to seven to indicate the intensity of their respect.

\subsubsection{Behavioral intentions}

Regarding behavioral intentions, twelve items measuring intention to purchase energy conserving household appliances were adapted from He \& Yang (2004) (e.g., "I will specialize in purchasing this kind of household appliances, if they perform well in China Energy label”). Using four different scenarios, our manipulations included different items to measure the likelihood of three types of effort that the consumer will make to buy energy conserving household appliances. Therefore, IPECHA is a second-order construct that was reflected by three first-order constructs, namely SP (specialize in purchasing), SRB (switch regular brand), and PMM (pay more money). Intention to resist non-energy conserving household appliances was also measured in the mentioned scenarios. That is, four items were designed to measure IRNCHA (e.g., "I wouldn't purchase this kind of household appliances, if they have a poor performance in China Energy label"). We have exhibited all of the first-order construction items in Table 4. The score from one to seven indicates the likelihood of efforts.

\subsection{Data collection}

The survey was conducted in Hangzhou, Zhejiang province, P. R. China. China is the biggest emerging country, which has begun to grow, but has yet to reach a mature stage of development (Yin \& Zhang, 2012). Hangzhou, a big city in the 
southeastern part of China, is the capital of Zhejiang Province. It covers an area of $16,600 \mathrm{~km}^{2}$ and has a population of 8,892,000 (2014). The city had a GDP of 920.116 billion RMB yuan (approximately US\$150.37 billion) in 2014, and a per capita GDP amounting to $103,757 \mathrm{RMB}$ yuan (approximately US\$16,956). To some extent, Hangzhou could represent the big cities of emerging countries.

Our research team, which has seven trained members, surveyed residents of the Cuiyuan subdistrict face-to-face from August 1-30, 2014. The Cuiyuan subdistrict is located in the downtown area of Hangzhou. It is a traditional comprehensive subdistrict that can represent most of the subdistricts in Hangzhou. To qualify for inclusion in the sample, all of the participants were randomly chosen from more than 18,000 households. During the survey, team members visited selected households and invited one of the family members to participate in our investigation. Each participant was asked to read the explication of an energy conserving household appliance and then complete a questionnaire. After the completed questionnaire passed our team member's integrity check, each participant was provided with gifts (e.g., toothpaste, detergent, tissues). In the end, 800 completed questionnaires were received. We reviewed them and removed the unqualified questionnaires. Finally, there were 775 useable responses, resulting in an overall effective response rate of $97 \%$.

The demographic characteristics of the samples were examined, and the results are shown in Table 3. The sample is made up of $49.4 \%$ female and $50.6 \%$ male, close to the ideal ratio 1:1, and the numbers from Hangzhou's official statistics are $48.77 \%$ female and 51.23\% male, respectively. Given the respondents' age ranges, the young and the middle-aged, which are the dominant buyers of household appliances, occupy a leading position (80.6\%). Education levels ranged from low, including Junior middle school or below, to university. The majority of respondents are graduates of university, which is in accord with the high educational level of the residents of big cities. With regard to personal income per month, the largest response group reported income less than $¥ 4,800$ (approximately US\$ 774)(44.1\%), followed by $¥ 6,400$ (approximately US\$1,032) or more $(20.5 \%$ ), then between $¥ 4,800$ and $¥ 6,400$ (approximately US\$ $774 \sim$ US\$1, 032)(17.3\%), and the rest are either undergraduate 
or postgraduate students $(18.1 \%)$ who are assumed to have no income.

-Insert Table 3 about here-

\subsection{Data analysis}

Instead of using covariance-based structural equation modeling (CB-SEM), we choose partial least squares structural equation modeling (PLS-SEM) to perform data analysis in a holistic manner, using SmartPLS version 2.0 (Ringle, Wende, \& Will, 2005). We use PLS-SEM (Hair, Ringle, \& Sarstedt, 2011), which has enjoyed increasing popularity in recent years, for the following reasons: (1) we are engaging in exploratory research, as there are no mature models or direct theories available for our hypotheses (Henseler et al., 2014); (2) our goal is to predict key target constructs, i.e., IPECHA and IRNCHA (Sarstedt, Ringle, Henseler, \& Hair, 2014); (3) our structural model is complex because it contains eight first-order constructs, one second-order construct, and 28 indicators (Willaby, Costa, Burns, MacCann, \& Roberts, 2015); (4) our data are, to some extent, non-normal according to the Q-Q plots (Hair, Sarstedt, Pieper, \& Ringle, 2012), but the sample size (775) is large enough for PLS-SEM, within a rough estimation that is based on the "ten times rule," as suggested by Barclay, Thompson, \& Higgins (1995).

\section{Results and discussion}

Based on the research data of 775 Hangzhou residents, a variance-based structural equation model (also known as PLS-SEM) was built using Smart PLS 2.0. 


\subsection{Measurement model}

A measurement model examines hypothesized links between indicators and latent constructs (Thatcher \& Perrewe, 2002). As the assessment of the measurement model in model 2 can fully reflect the measurement quality of model 1 , we present only the relevant information of model 2 .

\subsubsection{Internal consistency reliability}

Internal consistency reliability results are provided in Table 4. Because Cronbach's alpha is limited by the assumption that all indicators are equally reliable (tau-equivalence), efforts to maximize it can seriously compromise reliability (Raykov, 2007). In contrast, composite reliability (CR) does not assume tau-equivalence, making it more suitable for PLS-SEM, which prioritizes indicators according to their individual reliabilities (Hair, Sarstedt, Ringle, \& Mena, 2012). The data in Table 4 indicate that the measures are robust in terms of their internal consistency reliability, as indexed by the CR (Al-Gahtani, Hubona, \& Wang, 2007). The CRs of different measures range from 0.873 to 0.936 , exceeding the recommended threshold value of 0.70 (Nunnally, 1978; Bagozzi \& Yi, 1988).

\section{-Insert Table 4 about here-}

\subsubsection{Convergent validity}

Convergent validity indicates the extent to which the items of a scale that are theoretically related are also related in reality (Limayem, Hirt, \& Cheung, 2007). Table 4 presents information about the loadings of the research model's measures. All items have significant path loadings at the 0.001 level, and every reflective measure 
fulfills the recommended level concerning CR and average variance extracted (AVE). As recommended by Fornell \& Larcker (1981), all items were higher than 0.50, as shown in Table 4. All of the values of CR and AVE are considered satisfactory, with CR at 0.873 or above and AVE at 0.633 or above.

\subsubsection{Discriminant validity}

Discriminant validity represents the extent to which the construct is empirically distinct from other constructs. In other words, the construct measures what it is intended to measure (Hair, Sarstedt, Hopkins, \& Kuppelwieser, 2014). This validity was verified by using the square root of the AVE for each construct that was higher than the correlations between it and all other constructs (Fornell \& Larcker, 1981). Table 5 shows that the square roots of the AVEs are greater than the inter-construct correlations. Furthermore, based on this table, we find that IRNCHA is moderately correlated with $S R B, S P$, and $P M M$. All three correlation coefficients are smaller than 0.6 but larger than 0.5 .

\section{-Insert Table 5 about here-}

Following Chin (1998), we further use the cross-loading method to assess discriminant validity of the scales that were employed in testing our research model. Table 6 reports the loading and cross-loading of all reflective measures in the model. When reviewing the columns, we see that the item loadings in their corresponding columns are all higher than the loadings of the items used to measure the other constructs. Furthermore, when reviewing the rows, we find the item loadings to be higher for their corresponding constructs than for others. Therefore, our 
measurements satisfy the two criteria for discriminant validity suggested by Chin (1998). Thus, intention of sustainable consumption choices of household appliances can be divided effectively into intention to resist non-energy conserving household appliances and intention to purchase energy conserving household appliances. H3 is supported.

\section{-Insert Table 6 about here-}

While our findings pass the more technical criteria that is put forward in the literature, the existence of discriminant validity is also supported by theory. The correlation between pride and respect is relatively high at 0.729 , despite the fact that it passes the tests by Chin (1998) and Fornell \& Larcker (1981). Under certain circumstances, a correlation of this magnitude may indicate that the measurement taps into the same construct. We are, however, convinced that this is not a problem for the following reasons: (1) prior consumer behavior research is similar, in that the correlation coefficient between pride and gratitude is as large as 0.74 (Kim \& Johnson, 2014); and (2) from a theoretical point of view, it is not at all unusual that pride and respect correlate because they are both positive and elicited by the confirmation of subjective norms (Li \& Fischer, 2007; Williams \& DeSteno, 2008). As for the high correlation between anger and guilt (0.671), we also suppose this is not a large problem, as evidenced by (1) prior consumer behavior research is similar, in that the correlation coefficient between shame and anger is as large as 0.63 (Kim \& Johnson, 2014); and (2) these two emotions are both negative and elicited by the violations of subjective standards under our specific research conditions (Tangney et al., 2007; 
Baumeister et al., 2007).

\subsubsection{Common method variance}

Common method variance (CMV) refers to the amount of spurious covariance that is shared among variables due to the common method that is used in collecting data (Podsakoff, MacKenzie, Lee, \& Podsakoff, 2003). In consideration of the fact that we not only used many similar statements to measure psychological variables, but we also lacked a randomized question order for all constructs, there may be a CMV issue. To test for the possibility of CMV, we conducted Harmon's single-factor test (Podsakoff \& Organ, 1986) as a preliminary test. In this test, if a substantial amount of CMV is present in the data sample, either a single factor will emerge from the factor analysis, or one general factor will account for the majority of the covariance in the independent and dependent variables (Premkumar \& Bhattacherjee, 2008). A factor analysis of all items used in this study revealed five factors to explain $67.6 \%$ of the total variance, with the first factor explaining $42 \%$ of the variance and the last factor explaining $3.7 \%$ of the variance. These figures indicate that the variances are well distributed among multiple factors, suggesting that there is no CMV in our data sample.

Because of the limited capability of Harman's one-factor test to detect CMV (Podsakoff et al., 2003), we performed an additional test, as suggested by Pavlou, Liang, \& Xue (2007) and Siponen \& Vance (2010). Due to the limited space of this paper, we provide only the final results in Table 7 . The detailed guidelines of this test can be found in Siponen \& Vance (2010). According to Table 7, the variance of the 
indicators due to substantive constructs is substantially greater than that due the method construct. The average variance due to substantive constructs is $75.3 \%$, compared to $0.2 \%$ for the method construct. This result indicates that the influence of the method factor was considerably smaller than that due to substantial factors (Siponen \& Vance, 2010). Examining the loadings of the method factor, we find that the majority is insignificant. Therefore, we concluded that our results reflect a negligible influence due to $\mathrm{CMV}$, and $\mathrm{CMV}$ is not a concern.

-Insert Table 7 about here-

\subsection{Structural model}

Structural model estimates hypothesized paths between exogenous and endogenous latent constructs (Thatcher \& Perrewe, 2002).

\subsubsection{Path coefficients}

In line with the suggestions of Hair et al. (2011), Henseler, Ringle, \& Sinkovics (2009), and Henseler (2010), we used the path-weighting scheme to estimate path loadings. Because the jackknife method is viewed as less efficient than the bootstrap method, it can be considered to be an approximation of the bootstrap method (Tenenhaus, Amato, \& Esposito Vinzi, 2004). We apply bootstrapping (individual sign changes, 775 cases and 5000 samples) to assess the significance of the path coefficient. Fig. 2 presents the estimated parameters of the structural models. In model 1, the overall model explains $42 \%$ of IPECHA, and all of the four path coefficients are significant. Thus, H1 is supported in model 1. Moreover, the path 
coefficients of pride-IPECHA are the largest among the paths of the four emotions-IPECHA. In model 2, the overall model explains $56.8 \%$ of IPECHA and $25.4 \%$ of IRNCHA. All of the path coefficients, except anger-IRNCHA, are significant. Therefore, $\mathbf{H 1}$ is partly supported in model 2. The direct effects of pride on IPECHA and IRNCHA are the largest among the direct effects of emotions on these two behaviors, respectively. Therefore, $\mathbf{H 2}$ is supported.

--Insert Fig. 2 about here-

\subsection{2. $Q^{2}$ and $f^{2}$}

Cross-validated redundancy $\left(\mathrm{Q}^{2}\right)$ is a means of assessing the inner model's predictive relevance (Hair et al., 2014). A $\mathrm{Q}^{2}$ value larger than zero for a particular endogenous construct indicates the path model's predictive relevance for this particular construct, i.e., the corresponding endogenous construct can be predicted. We obtained $\mathrm{Q}^{2}$ by using the blindfolding procedure in SmartPLS (omission distance is 7). The $\mathrm{Q}^{2}$ in models 1 and 2 are both larger than zero.

The effect size for each path model can be determined by calculating Cohen's $f^{2}$, which is computed by noting the change in $\mathrm{R}^{2}$ when a specific construct is eliminated from the model (Hair, Hult, Ringle, \& Sarstedt, 2013). The specific method for calculating $f^{2}$ can be found in Hair et al. (2013). Table 8 presents the $f^{2}$ of emotions in models 1 and 2. Based on the $f^{2}$ value, although the effect size of the omitted construct for a particular endogenous construct can be determined such that $0.02,0.15$, and 0.35 represent small, medium, and large effects, respectively (Cohen, 1988), it is important to understand that a small $f^{2}$ does not necessarily imply an unimportant 
effect (Limayem et al., 2007). On the basis of Table 8, pride has the greatest potential to predict IRNCHA in model 2 or IPECHA in models 1 and model 2. By synthesizing the results of $f^{2}$ and the path coefficients, $\mathbf{H} 2$ is supported.

-Insert Table 8 about here-

\subsubsection{Mediation assessment}

Mediation exists if the coefficient of the direct path between the target independent variable and the dependent variable is reduced when the indirect path via the mediator is introduced into the model (Bontis, Booker, \& Serenko, 2007). We can assess whether this reduction, which represents the indirect effect, is significant only after the bootstrapping procedure has been run and the paths turn out to be significant. As shown in Fig. 2, the effect of anger on IRNCHA is insignificant, which means there is no need to assess the significance of the indirect effect of anger on IPECHA.

The rest of the emotions, i.e., respect, guilt, and pride, cannot be assessed by a visual inspection of the coefficients; they must be assessed mathematically (Bontis et al., 2007). Considering that the causal steps approach, popularized by Baron \& Kenny (1986), has many problems, and the Sobel test requires unstandardized path coefficients as inputs for the test statistics and lacks statistical power, we used bootstrapping to assess the significance of the indirect effects, as suggested by Hayes (2009). Specifically, we calculated the standard error of a target indirect effect, based on the bootstrapping result for the product of two relevant path coefficients using the function STDEV in MS Excel 2010 (Hair et al., 2013). Moreover, we introduce the variance accounted for (VAF) to determine the size of the indirect effect in relation to 
the total effect (Hair et al., 2013).

Table 9 illustrates three types of effects of the four emotions on IPECHA. According to this table, all of the direct and total effects are significant, and with the exception of anger, all of the indirect effects towards IPECHA are statistically significant. Because the three VAFs of respect towards IPECHA, guilt towards IPECHA, and pride towards IPECHA are larger than $20 \%$ but smaller than $80 \%$, this finding can be characterized as partial mediation (Hair et al., 2013). Therefore, because IRNCHA does not significantly mediate the impact of anger on IPECHA, $\mathbf{H 4}$ is partly supported. Moreover, the largest total effect of emotion on IPECHA is 0.405, which belongs to pride, followed by guilt $(0.157)$ and respect $(0.133)$, thus further confirming $\mathbf{H 2}$.

-Insert Table 9 about here-

\subsection{Discussion}

The paper explores the role that pride, respect, guilt, and anger have on the intention of sustainable consumption choices. Zhao, Gao, Wu, Wang, \& Zhu (2014) have studied the impact of cognitive factors (e.g., attitude, environment concern) and socio-demographics (e.g., age, income, education level) on green consumer behavior in an emerging country. However, our empirical study used a different perspective on the influential factors of emotions on this type of behavior. Our findings support the developed research hypotheses and expand the previous studies by providing a new perspective on the ways that pride, guilt, respect, and anger influence individual 
sustainable consumption choices with regard to household appliances.

Firstly, we confirm that pride, guilt, respect, and anger all have positive influences on the intention of sustainable consumption choices. Extant studies have special interests in the roles that pride and guilt have in motivating sustainable consumption behavior (Onwezen et al., 2013, 2014; Antonetti \& Maklan, 2014a), and few scholars have studied anger or respect in sustainable consumption behavior research. Our study finds that respect and anger are also valuable drivers of sustainable consumption behavior, and they should not be neglected in research on sustainable consumption.

Secondly, this study finds the difference in the effects of pride, guilt, respect, and anger on the intention of sustainable consumption choices, and heightens the role of pride among these four emotions in sustainable consumption. Despite an established research tradition that claims positive emotions have a stronger influence on sustainable consumption (Meneses, 2010; Koenig-Lewis et al., 2014), this exploratory study documents that not all types of positive emotions are more strongly correlated with sustainable consumption behavior than specific negative emotions. Future studies of the relationship between emotion and sustainable consumption should not use one latent variable to represent different positive or negative emotions (e.g., pride and respect or guilt and anger). This approach may mix the different effects of the emotions and weaken the study's practical implications.

Thirdly, the satisfactory convergent validity and discriminant validity results indicate that intention of sustainable consumption choices of household appliances 
has two facets: intention to resist non-energy conserving household appliances and intention to purchase energy conserving household appliances. Previous research has regarded purchasing sustainable products and resisting non-sustainable products as the same behavior (Roberts, 1996). However, our findings support that these behaviors can be separated. Thus sustainable consumption research can go deeper, and corresponding findings can be more useful.

Finally, we confirm that, by bootstrapping, IRNCHA is a mediator of the influence of pride, guilt, and respect on IPECHA. Specifically, when people plan to purchase an energy conserving household appliance, the emotions of pride, guilt, respect, and anger all can play notable roles. However, when they tend to resist non-energy conserving household appliances, only pride, guilt, and respect have significant and positive effects on their behavior, and thus influence IPECHA. In other words, under the circumstance of sustainable consumption, the purchase of energy conserving household appliances is the deepening development and final result of consumers' resistance to non-energy conserving household appliances. These findings provide a new perspective for future research.

\section{Conclusions and policy implications}

Most sustainable consumption studies tend to neglect the potential disparity in the impacts of different emotions on sustainable consumption choices. This research adds to the extant literature by (1) demonstrating the ability of pride and guilt to influence an individual's intention to buy energy conserving household appliances or 
resist non-energy conserving household appliances, as well as confirming the positive influences of respect and anger on the consumer's intention of sustainable consumption choices; (2) showing that the impact of a specific positive emotion on the intention of sustainable consumption choices may not be stronger than a specific negative emotion; and (3) finding two distinguishable facets of sustainable consumption choices. A better understanding of the ways various specific emotions can influence consumers' decisions in choosing sustainable products is a necessary step toward sustainable development.

This paper may have important policy implications for the promotion of sustainable consumption choices, especially in some emerging countries, such as China and India (both of them are classic symbols of the oriental culture and advocate collectivism). The results of our study suggest that by eliciting the emotions of pride, guilt, respect, and anger, we can influence the sustainable consumption choices of consumers. Specifically, pride is the best option when policy makers want to use emotional appeals to promote sustainable consumption. Another good idea is to provide respectable examples of sustainable consumption from which the target consumer population can learn. However, because guilt and anger are less powerful influences than pride on sustainable consumption choices, and they may backfire, policy makers should be prudent when appealing to the emotions of guilt or anger. Although we do not deem the use of guilt or anger appeal as morally questionable under the circumstances of emerging countries, generally speaking, we suggest that policy makers prefer to promote sustainable consumption behaviors through positive 
emotions, which are much less likely to lead to accidental consequences. Furthermore, we suggest that the policy of energy conserving promotion should include the purchase of energy conserving products, as well as the resistance of non-energy conserving products, with the latter behavior resulting in a positive impact on the former.

\section{Acknowledgments}

This study is supported by the National Science Foundation of China (Grant No. 71203192) and the Zhejiang Provincial Natural Science Foundation of China (Grant No. Y15G030053).

\section{References}

Al-Gahtani, S. S., Hubona, G. S., \& Wang, J. 2007. Information technology (IT) in saudi arabia: Culture and the acceptance and use of IT. Information \& Management, 44(8), 681-691.

Antonetti, P., \& Maklan, S. 2014a. Feelings that make a difference: how guilt and pride convince consumers of the effectiveness of sustainable consumption choices. Journal of Business Ethics, 124(1), 117-134.

Antonetti, P., \& Maklan, S. 2014b. Exploring postconsumption guilt and pride in the context of sustainability. Psychology \& Marketing, 31(9), 717-735.

Bagozzi, R. P., \& Yi, Y. 1988. On the evaluation of structural equation models. Journal of the Academy of Marketing Science, 16(1), 74-94.

Bamberg, S., \& Möser, G. 2007. Twenty years after hines, hungerford, and tomera: a new meta-analysis of psycho-social determinants of pro-environmental behaviour. Journal of Environmental Psychology, 27(1), 14-25.

Barclay, D., Thompson, R., \& Higgins, C. 1995. The partial least squares (PLS) approach to causal modeling: personal computer adoption and use as an illustration. Technology Studies, 2(2), 285-309.

Baron, R. M., \& Kenny, D. A. 1986. The moderator - mediator variable distinction in social psychological research: conceptual, strategic and statistical considerations. Journal of Personality and Social Psychology, 51(6), 1173-1182.

Baumeister, R. F., Vohs, K. D., DeWall, C. N., \& Zhang, L. 2007. How emotion shapes behavior: feedback, anticipation, and reflection, rather than direct causation. Personality and Social Psychology Review, 11(2), 167-203. 
Baumeister, R., Stillwell, A., \& Heatherton, T. 1995. Personal narratives about guilt: role in action control and interpersonal relationships. Basic and Applied Social Psychology, 17(1), 173-198.

Black, I. R., \& Cherrier, H. 2010. Anti-consumption as part of living a sustainable lifestyle: daily practices, contextual motivations and subjective values. Journal of Consumer Behaviour, 9(6), 437-453.

Bodolica, V., \& Spraggon, M. 2011. Behavioral governance and self-conscious emotions: unveiling governance implications of authentic and hubristic pride. Journal of Business Ethics, 100(3), 535-550.

Bontis, N., Booker, L. D., \& Serenko, A. 2007. The mediating effect of organizational reputation on customer loyalty and service recommendation in the banking industry. Management Decision, 45(9), 1426-1445.

Carrus, G., Passafaro, P., \& Bonnes, M. 2008. Emotions, habits and rational choices in ecological behaviours: the case of recycling and use of public transportation. Journal of Environmental Psychology, 28(1), 51-62.

Carver, C. S., Sinclair, S., \& Johnson, S. L. 2010. Authentic and hubristic pride: differential relations to aspects of goal regulation, affect, and self-control. Journal of Research in Personality, 44(6), 698-703.

Chatzidakis, A., \& Lee, M. S. W. 2013. Anti-Consumption as the study of reasons against. Journal of Macromarketing, 33(3), 190-203.

Chen, F. 2013. The intention and determining factors for airline passengers' participation in carbon offset schemes. Journal of Air Transport Management, 29, 17-22.

Chen, M. 2015. Extending the theory of planned behavior model to explain people's energy savings and carbon reduction behavioral intentions to mitigate climate change in taiwan - moral obligation matters. Journal of Cleaner Production, In press.

Cherrier, H., Black, I. R., \& Lee, M. 2011. Intentional Non - consumption for Sustainability. European Journal of Marketing, 45(11/12), 1757-1767.

Chin, W. W. 1998. The partial least squares approach to structural equation modeling. In G. A. Marcoulides (Ed.), Modern Methods for Business Research (295-336). Hillsdale, NJ: Lawrence Erlbaum Associates.

Cohen, J. 1988. Statistical power analysis for the behavioral sciences (2nded.). Hillsdale: L. Erlbaum Associates.

Corral-Verdugo, V., Bonnes, M., Tapia-Fonllem, C., Fraijo-Sing, B., Frias-Armenta, M., \& Carrus, G. 2009. Correlates of pro-sustainability orientation: the affinity towards diversity. Journal of Environmental Psychology, 29(1), 34-43.

Costa Pinto, D., Herter, M. M., Rossi, P., \& Borges, A. 2014. Going green for self or for others? Gender and identity salience effects on sustainable consumption. International Journal of Consumer Studies, 38(5), 540-549.

Fornell, C., \& Larcker, D. F. 1981. Evaluating structural equation models with unobservable variables and measurement error. Journal of Marketing Research, 18(1), 39-50.

Frijda, N. H. 1986. The emotions. Cambridge, UK: Cambridge University Press.

Frijda, N. H. 2007. The laws of emotion. Nawwah, NJ: Erlbaum.

Hair, J. F. J., Hult, G. T. M., Ringle, C. M., \& Sarstedt, M. 2013. A Primer on Partial Least Squares Structural Equation Modeling (PLS-SEM). Thousand Oaks, California: SAGE Publications, Inc. 
Hair, J. F. J., Ringle, C. M., \& Sarstedt, M. 2011. PLS-SEM: indeed a silver bullet. Journal of Marketing Theory and Practice, 19(2), 139-152.

Hair, J. F. J., Sarstedt, M., Hopkins, L., \& Kuppelwieser, V. G. 2014. Partial least squares structural equation modeling (PLS-SEM). European Business Review, 26(2), 106-121.

Hair, J. F. J., Sarstedt, M., Ringle, C. M., \& Mena, J. A. 2012. An assessment of the use of partial least squares structural equation modeling in marketing research. Journal of the Academy of Marketing Science, 40(3), 414-433.

Hair, J. F., Sarstedt, M., Pieper, T. M., \& Ringle, C. M. 2012. The use of partial least squares structural equation modeling in strategic management research: a review of past practices and recommendations for future applications. Long Range Planning, 45(5-6), 320-340.

Han, H. 2014. The norm activation model and theory-broadening: individuals' decision-making on environmentally-responsible convention attendance. Journal of Environmental Psychology, 40, 462-471.

Han, H., \& Ryu, K. 2012. The theory of repurchase decision-making (TRD): identifying the critical factors in the post-purchase decision-making process. International Journal of Hospitality Management, 31(3), 786-797.

Harth, N. S., Leach, C. W., \& Kessler, T. 2013. Guilt, anger, and pride about in-group environmental behaviour: different emotions predict distinct intentions. Journal of Environmental Psychology, 34, 18-26.

Hayes, A. F. 2009. Beyond baron and kenny: statistical mediation analysis in the new millennium. Communication Monographs, 76(4), 408-420.

He, Z., \& Yang, S. 2004. A Study about life style characteristics of green consumer. Nankai Business Review, 7(3), 4-10.

Henseler, J. 2010. On the convergence of the partial least squares path modeling algorithm. Computational Statistics, 25(1), 107-120.

Henseler, J., Dijkstra, T. K., Sarstedt, M., Ringle, C. M., Diamantopoulos, A., Straub, D. W., Ketchen, D. J., Hair, J. F., Hult, G. T. M., \& Calantone, R. J. 2014. Common Beliefs and Reality About PLS: Comments on Ronkko and Evermann (2013). Organizational Research Methods, 17(2), 182-209.

Henseler, J., Ringle, C. M., \& Sinkovics, R. R. 2009. The use of partial least squares path modeling in international marketing. Advances in International Marketing, 20, 277-319.

Ianos, I., Peptenatu, D., \& Zamfir, D. 2009. Respect for environment and sustainable development. Carpathian Journal of Earth and Environmental Sciences, 4(1), 81-93.

Kaiser, F. G. 2006. A moral extension of the theory of planned behavior: norms and anticipated feelings of regret in conservationism. Personality and Individual Differences, 41(1), 71-81.

Kals, E. 1996. Are proenvironmental commitments motivated by health concerns or by perceived justice? In L. Montada \& M. Lerner (Eds.), Current Societal Concern about Justice (231-258). New York: Plenum.

Kals, E., Schumacher, D., \& Montada, L. 1999. Emotional affinity toward nature as a motivational basis to protect nature. Environment and Behavior, 31(2), 178-202.

Kanchanapibul, M., Lacka, E., Wang, X., \& Chan, H. K. 2014. An empirical investigation of green purchase behaviour among the young generation. Journal of Cleaner Production, 66, 528-536.

Ketelaar, T., \& Tung Au, W. 2003. The effects of feelings of guilt on the behaviour of 
uncooperative individuals in repeated social bargaining games: an affect-as-information interpretation of the role of emotion in social interaction. Cognition \& Emotion, 17(3), 429-453.

Kim, J., \& Johnson, K. K. 2014. Shame or Pride? The moderating role of self-construal on moral judgments concerning fashion counterfeits. European Journal of Marketing, 48(7/8), 1431-1450.

Kim, Y. J., Njite, D., \& Hancer, M. 2013. Anticipated emotion in consumers' intentions to select eco-friendly restaurants: augmenting the theory of planned behavior. International Journal of Hospitality Management, 34, 255-262.

Koenig-Lewis, N., Palmer, A., Dermody, J., \& Urbye, A. 2014. Consumers' evaluations of ecological packaging - rational and emotional approaches. Journal of Environmental Psychology, 37, 94-105.

Leary, M. R. 2004. Digging deeper: The fundamental nature of "self-conscious" emotions. Psychological Inquiry, 15(2), 129-131.

Lee, J. A., \& Holden, S. J. S. 1999. Understanding the determinants of environmentally conscious behavior. Psychology and Marketing, 16(5), 373-392.

Li, J. 2001. Chinese conceptualization of learning. Ethos, 29(2), 111-137.

Li, J. 2003. US and chinese cultural beliefs about learning. Journal of Educational Psychology, 95(2), 258

Li, J. 2006. Respect in children across cultures. New Directions for Child and Adolescent Development(114), 81-90.

Li, J., \& Fischer, K. W. 2004. Thoughts and emotions in american and chinese cultural beliefs about learning. In D. Y. Dai \& R. Sternberg (Eds.), Motivation, Emotion, and Cognition: Integrative Perspectives on Intellectual Functioning and Development (385-418). Mahwah, NJ: Erlbaum.

Li, J., \& Fischer, K. W. 2007. Respect as a positive Self-conscious emotion in european americans and chinese. In J. L. Tracy, R. W. Robins \& J. P. Tangney (Eds.), The self-conscious emotions: theory and research (13, pp. 224-242). New York: The Guilford Press.

Limayem, M., Hirt, S. G., \& Cheung, C. M. K. 2007. How habit limits the predictive power of intention: the case of information systems continuance. MIS Quarterly, 31(4), 705-737.

Maddux, J. E., \& Rogers, R. W. 1983. Protection motivation and self-efficacy: a revised theory of fear appeals and attitude change. Journal of Experimental Social Psychology, 19(5), 469-479.

McFerran, B., Aquino, K., \& Tracy, J. L. 2014. Evidence for two facets of pride in consumption: findings from luxury brands. Journal of Consumer Psychology, 24(4), 455-471.

Meneses, G. D. 2010. Refuting fear in heuristics and in recycling promotion. Journal of Business Research, 63(2), 104-110.

Mesquita, B. 2003. Emotions as dynamic cultural phenomena. In N. Davidson, K. Scherer \& H. Goldsmith (Eds.), handbook of affective science (871-890). New York: Oxford University Press.

Mesquita, B., \& Frijda, N. H. 1992. Cultural variations in emotions: a review. Psychological Bulletin, 112(2), 179.

Nerb, J., \& Spada, H. 2001. Evaluation of environmental problems: a coherence model of cognition and emotion. Cognition and Emotion, 15(4), 521-551.

Nunnally, J. C. 1978. Psychometric theory. New York: McGraw-Hill.

Onwezen, M. C., Antonides, G., \& Bartels, J. 2013. The norm activation model: an exploration of the functions of anticipated pride and guilt in pro-environmental behaviour. Journal of 
Economic Psychology, 39, 141-153.

Onwezen, M. C., Bartels, J., \& Antonides, G. 2014. Environmentally friendly consumer choices: cultural differences in the self-regulatory function of anticipated pride and guilt. Journal of Environmental Psychology, 40, 239-248.

Oskamp, S. 2000. Psychological contributions to achieving an ecologically sustainable future for humanity. Journal of Social Issues, 56(3), 373-390.

Pavlou, P. A., Liang, H., \& Xue, Y. 2007. Understanding and mitigating uncertainty in online exchange relationships: a Principal-Agent perspective. MIS Quarterly, 31(1), 105-136.

Peattie, K. 2010. Green consumption: behavior and norms. Annual Review of Environment and Resources, 35(1), 195-228.

Peloza, J., White, K., \& Shang, J. Z. 2013. Good and Guilt-Free: the role of Self-Accountability in influencing preferences for products with ethical attributes. Journal of Marketing, 77(1), 104-119.

Perugini, M., \& Bagozzi, R. P. 2001. The role of desires and anticipated emotions in goal-directed behaviours: broadening and deepening the theory of planned behaviour. British Journal of Social Psychology, 40(1), 79-98.

Podsakoff, P. M., MacKenzie, S. B., Lee, J., \& Podsakoff, N. P. 2003. Common method biases in behavioral research: a critical review of the literature and recommended remedies. Journal of Applied Psychology, 88(5), 879-903.

Podsakoff, P. M., \& Organ, D. W. 1986. Self-reports in organizational research: problems and prospects. Journal of Management, 12(2), 531-544.

Premkumar, G., \& Bhattacherjee, A. 2008. Explaining information technology usage: a test of competing models. Omega-International Journal of Management Science, 36(1), 64-75.

Princen, T., Maniates, M., \& Conca, K. 2002. Confronting consumption. Cambridge, MA: MIT Press.

Prothero, A., Dobscha, S., Freund, J., Kilbourne, W. E., Luchs, M. G., Ozanne, L. K., \& Thøgersen, J. 2011. Sustainable consumption: opportunities for consumer research and public policy. Journal of Public Policy \& Marketing, 30(1), 31-38.

Raykov, T. 2007. Reliability if deleted, not 'alpha if deleted': evaluation of scale reliability following component deletion. British Journal of Mathematical and Statistical Psychology, 60(2), 201-216.

Ringle, C. M., Wende, S., \& Will, A. 2005. SmartPLS 2. Hamburg: SmartPLS.

Roberts, J. A. 1996. Green consumers in the 1990s: Profile and implications for advertising. Journal of Business Research, 36(3), 217-231.

Rozin, P., Lowery, L., Imada, S., \& Haidt, J. 1999. The CAD triad hypothesis: a mapping between three moral emotions (Contempt, anger, disgust) and three moral codes (Community, autonomy, divinity). Journal of Personality and Social Psychology, 76(4), 574-586.

Sandikc1, Ö., \& Ekici, A. 2009. Politically motivated brand rejection. Journal of Business Research, 62(2), 208-217.

Sarstedt, M., Ringle, C. M., Henseler, J., \& Hair, J. F. 2014. On the Emancipation of PLS-SEM: a Commentary on Rigdon (2012). Long Range Planning, 47(3), 154-160.

Schwartz, S. H. 1977. Normative influences on altruism. Advances in Experimental Social Psychology, 10, 221-279.

Siponen, M., \& Vance, A. 2010. Neutralization: new insights into the problem of employee 
information systems security policy violation. MIS Quarterly, 34(3), 487-502.

Swim, J. K., Stern, P. C., Doherty, T. J., Clayton, S., Reser, J. P., Weber, E. U., Gifford, R., \& Howard, G. S. 2011. Psychology's contributions to understanding and addressing global climate change. American Psychologist, 66(4), 241-250.

Tangney, J. P., Stuewig, J., \& Mashek, D. J. 2007. Moral emotions and moral behavior. Annual Review of Psychology, 58(1), 345-372.

Tanner, C., \& Kast, S. W. 2003. Promoting sustainable consumption: determinants of green purchases by swiss consumers. Psychology and Marketing, 20(10), 883-902.

Tenenhaus, M., Amato, S., \& Esposito Vinzi, V. (2004). A global goodness-of-fit index for PLS structural equation modelling. Paper presented at the Proceedings of the XLII SIS Scientific Meeting, CLEUP, Padova.

Testa, F., Cosic, A., \& Iraldo, F. 2016. Determining factors of curtailment and purchasing energy related behaviours. Journal of Cleaner Production, 112, 3810-3819.

Thatcher, J. B., \& Perrewe, P. L. 2002. An empirical examination of individual traits as antecedents to computer anxiety and computers Self-Efficacy. MIS Quarterly, 26(4), 381-396.

Tracy, J. L., Robins, R. W., \& Tangney, J. P. 2007. The Self-Conscious emotions: Theory and research. New York: The Guilford Press.

Tracy, J. L., \& Robins, R. W. 2004. Putting the self into self-conscious emotions: a theoretical model. Psychological Inquiry, 15(2), 103-125.

Tracy, J. L., \& Robins, R. W. 2007. The psychological structure of pride: a tale of two facets. Journal of Personality and Social Psychology, 92(3), 506-525.

Van Zomeren, M., Spears, R., \& Leach, C. W. 2010. Experimental evidence for a dual pathway model analysis of coping with the climate crisis. Journal of Environmental Psychology, 30(4), 339-346.

Willaby, H. W., Costa, D. S. J., Burns, B. D., MacCann, C., \& Roberts, R. D. 2015. Testing complex models with small sample sizes: a historical overview and empirical demonstration of what partial least squares (PLS) can offer differential psychology. Personality and Individual Differences, 84, 73-78.

Williams, L. A., \& DeSteno, D. 2008. Pride and perseverance: the motivational role of pride. Journal of Personality and Social Psychology, 94(6), 1007-1017.

Yin, J., \& Zhang, Y. 2012. Institutional dynamics and corporate social responsibility (CSR) in an emerging country context: evidence from china. Journal of Business Ethics, 111(2), 301-316.

Zhao, H., Gao, Q., Wu, Y., Wang, Y., \& Zhu, X. 2014. What affects green consumer behavior in china? a case study from Qingdao. Journal of Cleaner Production, 63, 143-151. 


\section{Figures}

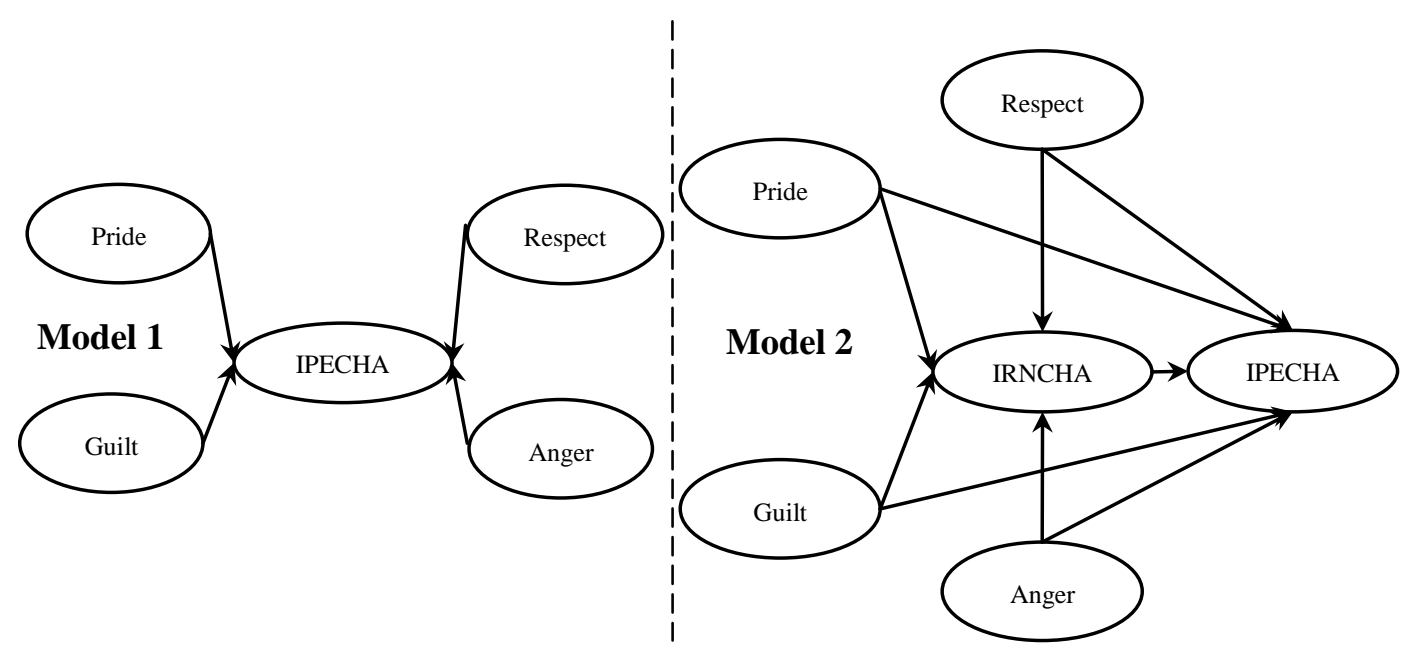

Fig. 1. Proposed conceptual models.

Note: IRNCHA = intention of resisting non-energy conserving household appliances; IPECHA = intention of purchasing energy conserving household appliances. 

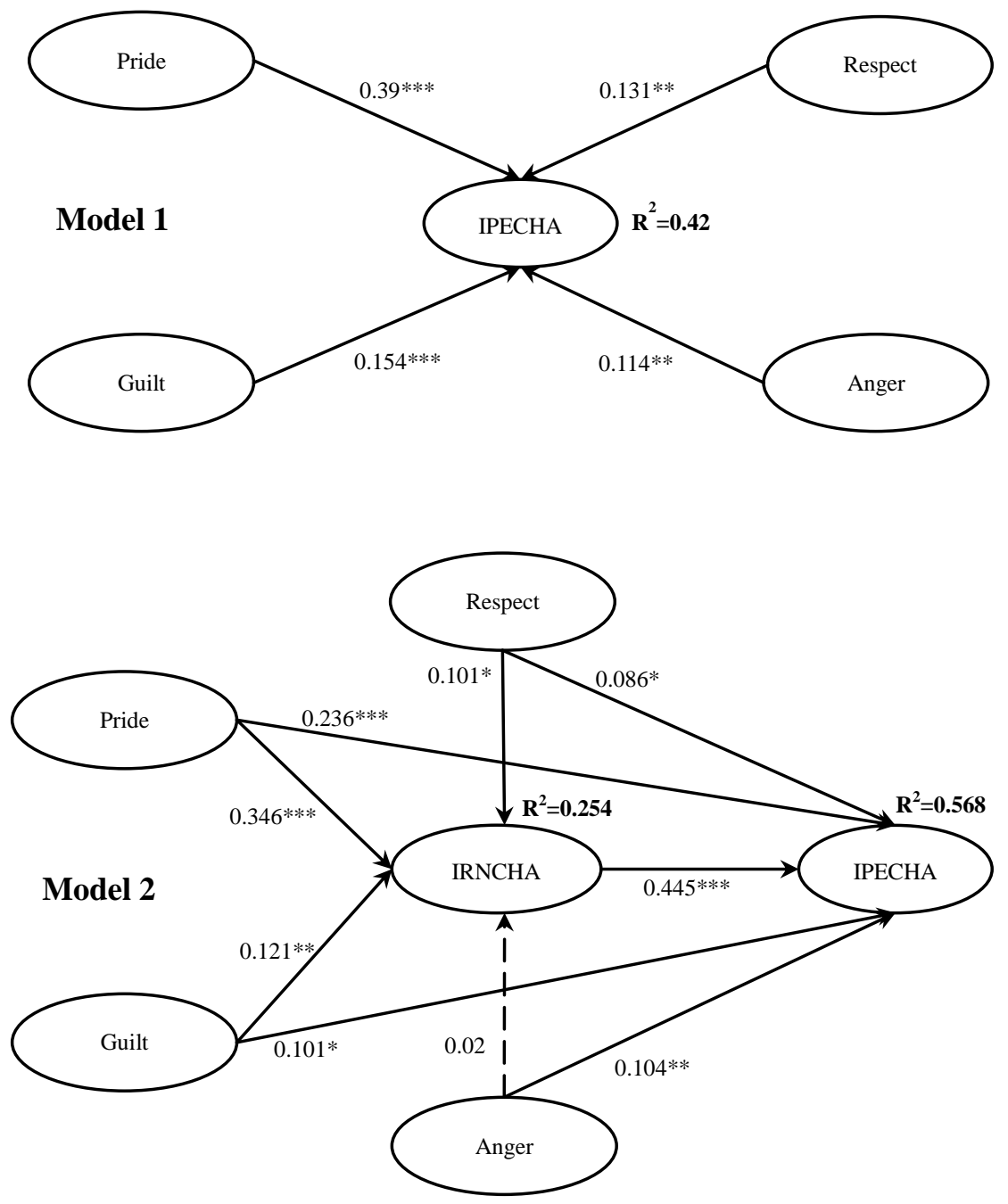

Fig. 2. PLS results of model testing.

Note: For reasons of clarity, we do not present lower-order latent variables of IPECHA, the item loadings, and standard errors; *p < 0.05; $* * \mathrm{p}<0.01 ; * * * \mathrm{p}<0.001$; IRNCHA = intention of resisting non-energy conserving household appliances; IPECHA = intention of purchasing energy conserving household appliances. 


\section{Tables}

Table 1

Description of moral emotions.

\begin{tabular}{cc|cc}
\hline & & \multicolumn{2}{c}{ Target object } \\
& & Self behavior & Others' behavior \\
\hline \multirow{2}{*}{ Valence } & Positive & Pride & Respect \\
& Negative & Guilt & Anger \\
\hline
\end{tabular}

Note: Pride, guilt, and respect are self-conscious emotions while anger is a basic emotion.

\section{Table 2}

Classification of consumption choices.

\begin{tabular}{ccc}
\hline & Energy conserving appliance & Non-energy conserving appliance \\
\hline Sustainable consumption behavior & purchase & resist \\
Unsustainable consumption behavior & resist & purchase \\
\hline
\end{tabular}

\section{Table 3}

Description of sample characteristics.

\begin{tabular}{|c|c|c|c|c|c|c|c|}
\hline Measure & Value & Frequency & Percent & Measure & Value & Frequency & Percent \\
\hline \multirow[t]{2}{*}{ Gender } & Male & 392 & $50.6 \%$ & Education & Junior middle school or below & 100 & $12.9 \%$ \\
\hline & Female & 383 & $49.4 \%$ & & Senior middle school & 166 & $21.4 \%$ \\
\hline \multirow[t]{5}{*}{ Age } & $18 \sim 24$ & 228 & $29.4 \%$ & & Technical college & 156 & $20.1 \%$ \\
\hline & $25 \sim 34$ & 286 & $36.9 \%$ & & University & 353 & $45.6 \%$ \\
\hline & $35 \sim 44$ & 111 & $14.3 \%$ & Income & Less than $¥ 4,800$ (approximately US\$ 774) & 342 & $44.1 \%$ \\
\hline & $45 \sim 54$ & 62 & $8 \%$ & & $\begin{array}{l}¥ 4,800 \sim ~ Y 6,400 \text { (approximately US\$ 774 } \\
\text { US\$1,032) }\end{array}$ & 134 & $17.3 \%$ \\
\hline & Over 54 & 88 & $11.4 \%$ & & Over $¥ 6,400$ (approximately US\$ 1, 032) & 159 & $20.5 \%$ \\
\hline
\end{tabular}

Note: There are 140 students (18.1\% of the total qualified participants) who are either undergraduate students or postgraduate students; they are assumed to have no income. 
Table 4

Psychometrical properties of the first-order constructs and second-order constructs.

\begin{tabular}{lcc}
\hline Construct & Factor & Mean \\
& SD & lom \\
\hline
\end{tabular}

First-order Constructs

\begin{tabular}{|c|c|c|c|c|}
\hline$(\mathrm{CR}=\mathbf{0 . 9 3 6}$ & feel satisfied (PR1) & 0.913 & 5.71 & 1.627 \\
\hline \multirow[t]{2}{*}{$\mathrm{AVE}=\mathbf{0 . 8 3 0}$ ) } & feel worthwhile (PR2) & 0.938 & 5.47 & 1.702 \\
\hline & feel proud (PR3) & 0.882 & 5.18 & 1.855 \\
\hline Respect & When people purchase energy conserving household appliances, I would & \multicolumn{2}{|c|}{ Source: designed by authors } & \\
\hline$(\mathrm{CR}=\mathbf{0 . 9 3 6}$ & admire them (RE1) & 0.906 & 5.59 & 1.751 \\
\hline \multirow[t]{2}{*}{$\mathrm{AVE}=\mathbf{0 . 8 3}$ ) } & appreciate them (RE2) & 0.941 & 5.43 & 1.7 \\
\hline & respect them (RE3) & 0.885 & 5.11 & 1.960 \\
\hline Guilt & When I purchase non-energy conserving household appliances, I would & \multicolumn{3}{|c|}{ Source: Onwezen et al. (2013) } \\
\hline$(\mathrm{CR}=\mathbf{0 . 9 2 0}$ & feel guilt (G1) & 0.882 & 4.40 & 1.986 \\
\hline $\mathrm{AVE}=\mathbf{0 . 7 9 4 )}$ & feel remorseful (G2) & 0.900 & 3.61 & 1.946 \\
\hline & feel bad (G3) & 0.891 & 3.85 & \\
\hline
\end{tabular}

Anger When people purchase non-energy conserving household appliances, I would Source: Harth et al. (2013)

$\begin{array}{llrl}(\mathbf{C R}=\mathbf{0 . 9 1 6} \text { feel resent }(\mathrm{AN} 1) & 0.870 & 4.33 & 1.927\end{array}$

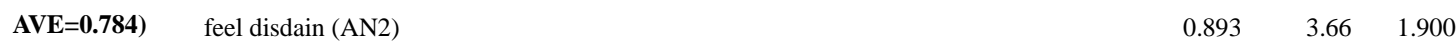

feel angry (AN3)

IRNCHA I wouldn't purchase this kind of household appliances, if

$0.893 \quad 3.54 \quad 1.958$

$(\mathbf{C R}=\mathbf{0 . 8 7 3}$ they have a poor performance in China Energy label (R1)

$\mathbf{A V E}=\mathbf{0 . 6 3 3}$ ) my relatives/friends believe that they waste electricity (R2)

I believe that they waste electricity (R3)

they don't have Energy Conservation Certification (R4)

SP

I will specialize in purchasing this kind of household appliances, if

$(\mathbf{C R}=\mathbf{0 . 9 1 2}$ they perform well in China Energy label (D1)

AVE=0.722) my relatives/friends believe that they save electricity (D2)

I believe that they save electricity (D3)

they have Energy Conservation Certification (D4)

SRB

I will switch my regular household appliances' band into a new one, if

$(\mathbf{C R}=\mathbf{0 . 9 1 2}$ they perform well in China Energy label (B1)

$\mathbf{A V E}=\mathbf{0 . 7 2 1}$ ) my relatives/friends believe that they save electricity (B2)

I believe that they save electricity (B3)

they have Energy Conservation Certification (B4)

PMM I will pay more money for this kind of household appliances, if

(CR=0.925 they perform well in China Energy label (P1)

$\mathbf{A V E}=\mathbf{0 . 7 5 5}) \quad$ my relatives/friends believe they save electricity $(\mathrm{P} 2)$

I believe that they save electricity (P3)

Source: designed by authors

$\begin{array}{lll}0.730 & 5.66 & 1.673 \\ 0.803 & 5.43 & 1.704 \\ 0.832 & 5.68 & 1.662 \\ 0.812 & 5.41 & 1.787\end{array}$

Source:He and Yang (2004)

$\begin{array}{lll}0.823 & 5.76 & 1.467 \\ 0.822 & 5.45 & 1.525 \\ 0.879 & 5.78 & 1.451 \\ 0.874 & 5.75 & 1.509\end{array}$

Source:He and Yang (2004)

$\begin{array}{lll}0.819 & 4.93 & 1.796 \\ 0.854 & 4.89 & 1.670 \\ 0.870 & 5.27 & 1.656 \\ 0.853 & 5.24 & 1.65\end{array}$

Source:He and Yang (2004)

$\begin{array}{lll}0.857 & 5.06 \quad 1.759\end{array}$

$0.866 \quad 4.91 \quad 1.661$

$\begin{array}{lll}0.878 & 5.26 & 1.649\end{array}$

they have Energy Conservation Certification (P4)

$0.875 \quad 5.20 \quad 1.682$

Second-order Constructs

Source:He and Yang (2004)

IPECHA 


\begin{tabular}{|c|c|c|c|c|}
\hline Construct & Item & $\begin{array}{l}\text { Factor } \\
\text { loading }\end{array}$ & Mean & SD \\
\hline$(\mathrm{CR}=0.919$ & SRB & 0.889 & - & - \\
\hline $\mathrm{AVE}=0.79$ ) & PMM & 0.883 & - & - \\
\hline
\end{tabular}

Note: The second column in second-order constructs contains the first-order constructs, which reflect the second-order construct; All of the factor loadings are significant at the 0.001 level; IRNCHA = intention of resisting non-energy conserving household appliances; IPECHA = intention of purchasing energy conserving household appliances; SP = specialize in purchasing; SRB = switch regular brand; $\mathrm{PMM}=$ pay more money.

\section{Table 5}

Intercorrelations of the latent variables for first-order constructs.

\begin{tabular}{|c|c|c|c|c|c|c|c|c|}
\hline Variable & Respect & Anger & SRB & SP & Guilt & PMM & Pride & IRNCHA \\
\hline Respect & 0.911 & & & & & & & \\
\hline Anger & 0.345 & 0.885 & & & & & & \\
\hline SRB & 0.458 & 0.375 & 0.849 & & & & & \\
\hline SP & 0.497 & 0.394 & 0.702 & 0.850 & & & & \\
\hline Guilt & 0.438 & 0.671 & 0.445 & 0.461 & 0.891 & & & \\
\hline PMM & 0.435 & 0.311 & 0.669 & 0.679 & 0.344 & 0.869 & & \\
\hline Pride & 0.729 & 0.368 & 0.520 & 0.594 & 0.464 & 0.482 & 0.911 & \\
\hline IRNCHA & 0.413 & 0.263 & 0.598 & 0.577 & 0.339 & 0.573 & 0.483 & 0.795 \\
\hline
\end{tabular}

Note: Diagonal elements are square root of AVEs. For adequate discriminant validity, diagonal elements should be greater than corresponding off-diagonal elements. IRNCHA = intention of resisting non-energy conserving household appliances; $\mathrm{SP}=$ specialize in purchasing; $\mathrm{SRB}=$ switch regular brand; $\mathrm{PMM}=$ pay more money. 
Table 6

Loadings and cross-loadings of all reflective measures.

\begin{tabular}{|c|c|c|c|c|c|c|c|c|}
\hline & Respect & Anger & SRB & SP & Guilt & Pride & PMM & IRNCHA \\
\hline RE1 & 0.906 & 0.332 & 0.396 & 0.457 & 0.393 & 0.638 & 0.395 & 0.383 \\
\hline RE2 & 0.941 & 0.304 & 0.437 & 0.470 & 0.404 & 0.699 & 0.422 & 0.411 \\
\hline RE3 & 0.885 & 0.308 & 0.421 & 0.430 & 0.401 & 0.654 & 0.369 & 0.330 \\
\hline AN1 & 0.312 & 0.870 & 0.362 & 0.407 & 0.577 & 0.369 & 0.284 & 0.241 \\
\hline AN2 & 0.274 & 0.893 & 0.307 & 0.299 & 0.576 & 0.273 & 0.261 & 0.206 \\
\hline AN3 & 0.325 & 0.893 & 0.322 & 0.330 & 0.626 & 0.327 & 0.279 & 0.248 \\
\hline B1 & 0.355 & 0.325 & 0.819 & 0.532 & 0.384 & 0.398 & 0.563 & 0.440 \\
\hline B2 & 0.407 & 0.303 & 0.854 & 0.600 & 0.349 & 0.440 & 0.583 & 0.519 \\
\hline B3 & 0.381 & 0.307 & 0.870 & 0.605 & 0.370 & 0.448 & 0.555 & 0.541 \\
\hline B4 & 0.411 & 0.339 & 0.853 & 0.643 & 0.409 & 0.476 & 0.573 & 0.527 \\
\hline D1 & 0.411 & 0.343 & 0.583 & 0.823 & 0.417 & 0.509 & 0.536 & 0.473 \\
\hline D2 & 0.443 & 0.332 & 0.567 & 0.822 & 0.372 & 0.489 & 0.558 & 0.464 \\
\hline D3 & 0.422 & 0.321 & 0.611 & 0.879 & 0.383 & 0.516 & 0.604 & 0.521 \\
\hline D4 & 0.415 & 0.345 & 0.624 & 0.874 & 0.395 & 0.505 & 0.607 & 0.502 \\
\hline G1 & 0.412 & 0.615 & 0.434 & 0.468 & 0.882 & 0.435 & 0.311 & 0.336 \\
\hline G2 & 0.368 & 0.585 & 0.368 & 0.384 & 0.900 & 0.406 & 0.310 & 0.261 \\
\hline G3 & 0.385 & 0.589 & 0.379 & 0.369 & 0.891 & 0.394 & 0.297 & 0.300 \\
\hline PR1 & 0.667 & 0.365 & 0.471 & 0.588 & 0.443 & 0.913 & 0.423 & 0.446 \\
\hline PR2 & 0.678 & 0.331 & 0.479 & 0.546 & 0.426 & 0.938 & 0.449 & 0.460 \\
\hline PR3 & 0.647 & 0.310 & 0.472 & 0.486 & 0.399 & 0.882 & 0.448 & 0.412 \\
\hline P1 & 0.344 & 0.249 & 0.540 & 0.539 & 0.280 & 0.377 & 0.857 & 0.448 \\
\hline P2 & 0.406 & 0.297 & 0.588 & 0.619 & 0.304 & 0.410 & 0.866 & 0.472 \\
\hline P3 & 0.378 & 0.264 & 0.576 & 0.608 & 0.308 & 0.443 & 0.878 & 0.530 \\
\hline P4 & 0.382 & 0.271 & 0.620 & 0.592 & 0.302 & 0.442 & 0.875 & 0.536 \\
\hline R1 & 0.287 & 0.177 & 0.471 & 0.435 & 0.254 & 0.355 & 0.394 & 0.730 \\
\hline $\mathbf{R 2}$ & 0.382 & 0.194 & 0.448 & 0.456 & 0.244 & 0.392 & 0.456 & 0.803 \\
\hline $\mathbf{R 3}$ & 0.308 & 0.202 & 0.453 & 0.475 & 0.260 & 0.387 & 0.486 & 0.832 \\
\hline R4 & 0.334 & 0.259 & 0.529 & 0.469 & 0.317 & 0.399 & 0.481 & 0.812 \\
\hline
\end{tabular}

Note: IRNCHA = intention of resisting non-energy conserving household appliances; SP = specialize in purchasing; SRB = switch regular brand; $\mathrm{PMM}=$ pay more money. 
Table 7

The results of common method variance analysis.

\begin{tabular}{|c|c|c|c|c|c|}
\hline Construct & Indicator & $\begin{array}{c}\text { Substantive Factor } \\
\text { Loading }\end{array}$ & $\begin{array}{c}\text { Variance } \\
\text { Explained } 1\end{array}$ & $\begin{array}{l}\text { Method Factor } \\
\text { Loading }\end{array}$ & $\begin{array}{c}\text { Variance } \\
\text { Explained } 2\end{array}$ \\
\hline \multirow[t]{3}{*}{ Pride } & PR1 & $0.887 * * *$ & 0.787 & 0.032 & 0.001 \\
\hline & PR2 & $0.951 * * *$ & 0.904 & -0.017 & 0.000 \\
\hline & PR3 & $0.895 * * *$ & 0.802 & -0.015 & 0.000 \\
\hline \multirow[t]{3}{*}{ Respect } & RE1 & $0.906^{* * * *}$ & 0.821 & -0.003 & 0.000 \\
\hline & RE2 & $0.927 * * *$ & 0.860 & 0.016 & 0.000 \\
\hline & RE3 & $0.901 * * *$ & 0.811 & -0.014 & 0.000 \\
\hline \multirow[t]{3}{*}{ Guilt } & G1 & $0.805 * * *$ & 0.649 & $0.091 * * *$ & 0.008 \\
\hline & $\mathrm{G} 2$ & $0.946 * * *$ & 0.896 & $-0.054 * *$ & 0.003 \\
\hline & G3 & $0.921 * * *$ & 0.849 & -0.036 & 0.001 \\
\hline \multirow[t]{3}{*}{ Anger } & AN1 & $0.817 * * *$ & 0.668 & $0.066^{* *}$ & 0.004 \\
\hline & AN2 & $0.945 * * *$ & 0.892 & $-0.068 * * *$ & 0.005 \\
\hline & AN3 & $0.893 * * *$ & 0.798 & 0.004 & 0.000 \\
\hline \multirow[t]{4}{*}{ IRNCHA } & $\mathrm{R} 1$ & $0.727 * * *$ & 0.528 & 0.005 & 0.000 \\
\hline & $\mathrm{R} 2$ & $0.813 * * *$ & 0.660 & -0.013 & 0.000 \\
\hline & $\mathrm{R} 3$ & $0.873 * * *$ & 0.762 & -0.049 & 0.002 \\
\hline & $\mathrm{R} 4$ & $0.765 * * *$ & 0.586 & 0.058 & 0.003 \\
\hline \multirow[t]{4}{*}{ SP } & D1 & $0.804 * * *$ & 0.646 & 0.024 & 0.001 \\
\hline & D2 & $0.819 * * *$ & 0.671 & 0.004 & 0.000 \\
\hline & D3 & $0.897 * * *$ & 0.805 & -0.023 & 0.001 \\
\hline & D4 & $0.876 * * *$ & 0.767 & -0.003 & 0.000 \\
\hline \multirow[t]{4}{*}{ SRB } & B1 & $0.873 * * *$ & 0.762 & -0.061 & 0.004 \\
\hline & B2 & $0.853 * * *$ & 0.727 & 0.001 & 0.000 \\
\hline & B3 & $0.900 * * *$ & 0.810 & -0.036 & 0.001 \\
\hline & B4 & $0.772 * * *$ & 0.595 & $0.095^{*}$ & 0.009 \\
\hline \multirow[t]{4}{*}{ PMM } & $\mathrm{P} 1$ & $0.944 * * *$ & 0.891 & $-0.104 *$ & 0.011 \\
\hline & $\mathrm{P} 2$ & $0.838 * * *$ & 0.702 & 0.034 & 0.001 \\
\hline & P3 & $0.860 * * *$ & 0.740 & 0.021 & 0.000 \\
\hline & $\mathrm{P} 4$ & $0.836^{* * * *}$ & 0.699 & 0.047 & 0.002 \\
\hline Average & & 0.866 & 0.753 & 0.000 & 0.002 \\
\hline
\end{tabular}

Note: Variance Explained = Factor Loading ^2; IRNCHA = intention of resisting non-energy conserving household appliances; SP = specialize in purchasing; $\mathrm{SRB}=$ switch regular brand; $\mathrm{PMM}=$ pay more money. 
Table 8

Cohen's $f^{2}$ in models 1 and 2 .

\begin{tabular}{ccccccc}
\hline & Emotion & & Respect & Anger & Guilt & Pride \\
\hline$f^{2}$ (IRNCHA) & Model 2 & 0.002 & 0.000 & 0.004 & 0.025 \\
\multirow{2}{*}{$f^{2}$ (IPECHA) } & Model 1 & 0.007 & 0.007 & 0.011 & 0.063 \\
& Model 2 & 0.007 & 0.010 & 0.008 & 0.039 \\
\hline
\end{tabular}

Note: IRNCHA = intention of resisting non-energy conserving household appliances; IPECHA = intention of purchasing energy conserving household appliances.

Table 9

The results of partial least squares path model analysis.

\begin{tabular}{|c|c|c|c|c|c|}
\hline Path & & Respect $\rightarrow$ IPECHA & Anger $\rightarrow$ IPECHA & Guilt $\rightarrow$ IPECHA & Pride $\rightarrow$ IPECHA \\
\hline \multirow{3}{*}{ DE } & value & $0.071^{*}$ & $0.086^{* *}$ & $0.084 *$ & $0.196^{* * *}$ \\
\hline & SE & 0.03 & 0.03 & 0.033 & 0.035 \\
\hline & T statistics & 2.356 & 2.914 & 2.53 & 5.58 \\
\hline \multirow{3}{*}{ IE } & value & $0.061 * *$ & 0.011 & $0.073^{* *}$ & $0.209 * * *$ \\
\hline & SE & 0.023 & - & 0.028 & 0.034 \\
\hline & T statistics & 2.603 & - & 2.616 & 6.057 \\
\hline \multirow{4}{*}{ TE } & value & $0.133^{* *}$ & $0.098^{*}$ & $0.157 * * *$ & $0.405^{* * *}$ \\
\hline & SE & 0.044 & 0.038 & 0.042 & 0.047 \\
\hline & T statistics & 3.010 & 2.558 & 3.755 & 8.628 \\
\hline & VAF & $46.1 \%$ & - & $46.6 \%$ & $51.6 \%$ \\
\hline
\end{tabular}

Note: $\mathrm{DE}=$ direct effect, $\mathrm{IE}=$ indirect effect, $\mathrm{TE}=$ total effect, $\mathrm{VAF}=$ variance accounted for, $\mathrm{SE}=$ standard error; $*_{\mathrm{p}}<0.05 ; * * \mathrm{p}<0.01$;

$* * * \mathrm{p}<0.001 ;$ IPECHA $=$ intention of purchasing energy conserving household appliances. 